\title{
PENCEGAHAN DEMENSIA/ALZHEIMER DI DESA PRIGEN, KECAMATAN PRIGEN, KABUPATEN PASURUAN
}

\author{
Yurilla Endah Muliatie ${ }^{1}$, Nur Jannah ${ }^{2}$, Sri Suprapti ${ }^{3}$ \\ ${ }^{1,2,3}$ Universitas Wijaya Putra
}

yurillaendah@uwp.ac.id, nurjannah@uwp.ac.id, srisuprapti@uwp.ac.id

\begin{abstract}
Abstrak
Peningkatan presentase penyakit demensia di Indonesia antara lain 0,5\% per tahun pada usia 65-69 tahun, $1 \%$ per tahun pada usia 70-74 tahun, $2 \%$ per tahun pada usia 75-79 tahun, $3 \%$ per tahun pada usia 80-84 tahun dan $8 \%$ per tahun pada usia $>85$ tahun. Indonesia melaporan tentang gangguan demensia masih simpang siur, hal ini dapat dimengerti karena permasalahan mengenai pikun itu sendiri masih dipengaruhi mitos bahwa sudah semestinya orang berusia lanjut itu pikun Seiring dengan menurunnya kemampuan fungsi tubuh, senam lansia akan membantu tubuh tetap bugar dan segar karena melatih tulang tetap kuat, mendorong jantung bekerja optimal, dan membantu menghilangkan radikal bebas yang berkeliaran di dalam tubuh. Senam lansia akan membuat aliran darah menjadi lancar sehingga aliran oksigen ke otak juga lancer. Oksigenasi yang baik akan membuat organ-organ tubuh lainnya tetap sehat dan terhindar dari kemungkinan berbagai macam penyakit termasuk demensia. Di Desa Prigen khususnya, pengidap penyakit ini ada sekitar 10 orang dimana pada awalnya pihak keluarga hanya menganggap jika hal tersebut hanya penyakit pikun biasa. Oleh karena itu kami bermitra dengan puskesmas khususnya koordinator Posyandu Lansia untuk memberikan edukasi mengenai Alzheimer. Metode pelaksanaan dilakukan dengan pelatihan senam Alzheimer. Dan diharapkan dengan program edukasi secara prokes di saat pandemi ini bisa membantu para Lansia untuk tetap sehat dan bisa melakukan segala aktivitas. Hasil dari kegiatan ini masyarakat Prigen khususnya mengerti mengenai apa dan bagaimana penyakit Demensia/Alzheimer ini serta bagaimana cara pencegahannya. Dampaknya diharapkan angka penderita Demensia/Alzheimer ke depannya bisa ditekan semaksimal mungkin.
\end{abstract}

Kata Kunci: Demensia/Alzheimer, edukasi, senam lansia

\section{PENDAHULUAN}

Salah satu hal yang paling dikhawatirkan seseorang adalah ketika usianya mulai menua adalah menjadi pikun dan sulit mengingat memori baru. Demensia atau kepikunan, dewasa ini bukan hanya terjadi pada usia lanjut namun juga usia muda. Seseorang yang mengalami demensia, akan terjadi penurunan fungsi intelektual yang menyebabkan deteriorasi (kemunduran) kognisi dan fungsional, sehingga mengakibatkan gangguan fungsi sosial, pekerjaan dan aktivitas sehari-hari, oleh karena itu aktivitas sosialnya juga akan terganggu. Orang dengan demensia juga akan kehilangan kemampuan untuk menyelesaikan masalah dan menjada emosi.

Kepedulian terhadap Alzheimer dimulai dari Konferensi Alzheimer's Disesase International 
(ADI) di Edinburg pada tahun 1994 dengan mencanangkan tanggal 21 September sebagai hari Alzheimer sedunia. Pencanangan ini sebagai bentuk dukungan pada perkumpulan Alzheimer baik nasional maupun lokal dalam upaya meningkatkan kesadaran akan pentingnya penanganan yang serius terhadap gangguan Alzheimer, dengan pendekatan pada pemerintah sebagai pemegang kebijakan dan masyarakat agar mampu menghilangkan paradigma yang salah mengenai Alzheimer yang beredar saat ini. Pada tahun 2004, Alzheimer's Disease International telah menyepakati sebuah deklarasi yang berisi 10 rekomendasi tentang kebutuhan aksi minimal untuk perawatan orang dengan demensia yang dihasilkan di Kyoto Jepang dan dikenal dengan Kyoto Declaration.

Pada tahun 2012, WHO dan Alzheimer's Disease International (ADI) melaporkan di seluruh dunia diperkirakan 35,6 juta orang hidup dengan Demensia. Jumlah ini diperkirakan menjadi dua kali pada tahun 2030 dan tiga kali atau sekitar 115 juta orang pada tahun 2050. Biaya global untuk demensia ini diperkirakan sebesar 604 USD per tahunnya. Atas dasar laporan ini, WHO dan ADI menghimbau semua negara untuk meningkatkan kesadaran bahwa demensia saat ini merupakan "prioritas kesehatan masyarakat", untuk itu diperlukan advokasi "pendekatan kesehatan masyarakat" sebagai upaya untuk mengatasi masalah demensia ini dengan memberikan prioritas pada penguatan negara mempersiapkan kesiapsiagaan terhadap demensia mengembangkan sistem kesehatan dan sosial, dukungan bagi perawatan informal dan caregiver serta meningkatkan kesadaran dan advokasi terhadap masalah demensia.

WHO memperkirakan jumlah kasus Alzheimer di Indonesia berjumlah 1 juta orang pada tahun 2011, namun kondisi ini dapat terus bertambah seiring berjalannya waktu serta makin meningkatnya umur harapan hidup masyarakat Indonesia. Jumlah ini juga seperti fenomena gunung es, banyak masyarakat yang tidak melaporkan kondisinya karena ketidaktahuan bahwa Alzheimer atau Demensia adalah penyakit. Kurangnya informasi mengenai tanda, gejala dan penenganan Alzheimer di Indonesia masih sangat memprihatinkan. Pelayanan kesehatan untuk orang dengan demensia ini hanya terbatas pada pelayanan kesehatan rujukan yang ditangani oleh dokter spesialis, sementara pelayanan primer masih belum memiliki kemampuan untuk melakukan upaya penanganan masalah demensia ini.

Saat ini dikenal ada dua jenis demensia, yakti demensia vaskuler dan non vaskuler. Demensia vaskuler yang disebut sebagai Alzheimer merupakan kepikunan yang disebabkan adanya sumbatan di pembuluh darah otak. Dan diperkirakan $75 \%$ demensia vaskuler (Alzheimer) disebabkan oleh stroke sumbatan. Sumbatan tersebut bisa total dan bisa sebagian. Kalau sumbatannya sedikit maka orang dengan demensia kadang-kadang berperilaku baik dan kadang-kadang perasaan dan perilakunya jelek. Kalau daerah yang tersumbat di bagian otak yang berhubungan dengan memori, budaya, bicara, etika, moral, maka fungsi yang berhubungan dengan ingatan, budaya, bicara, etika, moral ini akan terganggu dan tidak berfungsi. Stroke sumbatan ini penyebab paling banyak adalah hipertensi, kolesterol, diabetes melitus, asam urat tinggi, kurang minum, kurang olah raga. Sedangkan demensia non vaskuler disebabkan oleh tumor otak, kanker otak, kekurangan vitamin, mineral, antioksidan, karena kebanyakan mengonsumsi alkohol, karena infeksi meningitis, encephalitis, pikiran kecewa, depresi dan obat-obatan. Beberapa yang beresiko terkena Alzheimer adalah orang lanjut usia (lebih dari 60 tahun), punya riwayat keluarga terkena Alzheimer, penderita stroke, gangguan jantung, diabetes dan cedera kepala otak.

Masyarakat perlu mengenali gejala awal demensia seperti mudah lupa, gangguan dalam berbahasa, disorientasi (waktu, tempat, orang), kesulitan mengambil keputusan, kemunduran (motivasi, inisiatif, minat) serta adanya tanda-tanda depresi. Jika penyakit demensia sudah parah maka akan terjadi ketergantungan pada orang lain dalam hal penderita mengalami sulit makan, tidak kenal anggota keluarga, sulit menahan buang air kecil dan besar, serta gangguan perilaku yang sangat berat. Ada 10 (sepuluh) tanda-tanda dini demensia/Alzheimer yang dapt dikenali sebelum pikun menjadi tahap lanjut yakni penurunan daya ingat misalnya lupa nama, lupa tempat menaruh 
benda; kebingungan dimana penderita penyakit Alzheimer dapat tersesat ketika keluar rumah sendirian dan kadang tidak dapat mengingat dimana dia atau bagaimana dia bisa sampai disana; kesulitan melakukan tugas-tugas yang lazim; kesulitan mengerjakan kebiasaan sehari-hari, seperti makan, mandi, berpakaian, dan lain-lain; perubahan kepribadian dan perilaku penderita penyakit Alzheimer yang menjadi mudah marah, tersinggung, gelisah, atau pendiam, kadang-kadang menjadi bingung, paranoid atau ketakutan; ketidakmampuan untuk mengikuti petunjuk; adanya masalah dengan bahasa dan komunikasi, seperti tidak dapat mengingat kata-kata, nama benda-benda atau memahami arti kata-kata umum; memburuknya kemampuan visual dan spasial, seperti menilai bentuk dan ukuran suatu benda; kehilangan motivasi atau inisiatif' kehilangan pola tidur normal.

Masyarakat harus meningkatkan pemahaman dan kepedulian terhadap gangguan Demensia/Alzheimer, menumbuhkan kesadaran akan bahaya Demensia/Alzheimer, melakukan penangan yang tepat pada penderita Demensia/Alzheimer maka beberapa hal dapat dilakukan yakni menurunkan/menjaga kadar kolesterol dalam darah, menurunkan/menjaga tekanan darah, mengendalikan diabetes, berolahraga secara teratur, terlibat dalam kegiatan yang merangsang pikiran, peningkatan kualitas hidup dan diet sehat dan gizi seimbang. Selain itu penderita Demensia/Alzheimer disarankan untuk melakukan beberapa diet buah dan sayuran berwarna oranye dan hijau seperti wortel terbukti bermanfaat untuk penundaan penurunan kognitif hingga 13 tahun lamanya. Dimana antioksidan karotenoid yagn dikandung buah dan sayur berwarna oranye dan hijau yang menghasilkan pigmen berwarna cerah pada buah dan sayuran tertentu ini dapat membantu menetralkan radikal bebas (molekul-molekul yang bisa merusak sel-sel tubuh), termasuk melindungi tubuh dari berbagai gangguan misalnya kanker, diabetes. Sayuran berdaun hijau, wortel, labu dan ubi jalar sarat akan karotenoid. Di samping itu juga mengajak otak agar terus aktif, misalnya dengan mengerjakan teka-teki silang akan mempertahankan ingatan hingga usia senja.
Orang dengan Demensia/Alzheimer akan mengalami kemunduran otak. Memori yang baru hilang tetapi memori yang lama diingat, misalnya memori masa kecilnya. Penampilan orang dengan Demensia/Alzheimer bisa macam-macam, bisa menjadi agitasi atau marah-marah, mengumpat, melempar, mengamuk dan kadang bisa membunuh orang dan ada juga yang diam. Dimana orang DemensialAlzheimer yang cenderung diam ini berbahaya. Oleh karena itu orang dengan DemensialAlzheimer harus dijaga jangan sampai berperasaan sedih. Orang dengan DemensialAlzheimer tidak membutuhkan rasionalitas. Orang dengan DemensialAlzheimer harus dibuat senang, dipuji bila melakukan tindakan yang baik. Dan diusahakan memanfaatkan yang masih bisa difungsikan pada dirinya misalnya dengan mengisi kegiatan yang bermanfaat seperti menyanyi, membaca atau membuat puisi, menggambar dan lain-lain sesuai kemampuan yang ada saat ini. Buatlah orang dengan DemensialAlzheimer menjadi bermartabat dan orang yang mendampinginya (caregive) harus tabah, sabar dan bisa mengerti agar orang dengan DemensialAlzheimer tidak melakukan hal-hal yang berbahaya. Dalam penanganannya belum ada obat yang dapat menyembuhkan DemensialAlzheimer namun perlu mendapatkan perhatian yang serius dan komitmen semua pihak dalam membantu keberhasilan penanganan penyakit DemensialAlzheimer. Beberapa hal yang dapat dilakukan antara lain adalah pihak keluarga yang berperan dalam merawat pasien DemensialAlzheimer hendaknya menghindari perbedaan pendapat; latihlah otak dengan permainan (interaksi sosial, pengembangan hobi); pantau kesehatan secara berkala; jauhi sikap (mengkritik, komentar negatif, berdebat, memaksa keinginan); merawat pasien DemensialAlzheimer hendaknya memiliki sikap tenang dan memaklumi; berilah penghargaan dan pujian; perlakukan penderita DemensialAlzheimer sebagai orang dewasa terbatas bukan sebagai anak kecil; berilah kegiatan yang bersifat rekreatif, humor dan menyenangkan; ciptakan lingkungan yang nyaman (tidak bising, penerangan cukup, lingkungan yang bersahabat). Selain itu konseling intensif bagi anggota keluara dan caregiver sangat diperlukan 
untuk mengatasi stres bagi penderita dan keluarga serta mencari solusi atas masalah-masalah yang dihadapi.

Sebagaimana diketahui orang dengan DemensialAlzheimer akan mengalami gangguan dalam beberapa hal seperti telah disebutkan diatas. Oleh karena itu dalam kehidupannya sehari-hari orang dengan DemensialAlzheimer tidak mampu menjalankan aktifitas ekonominya secara maksimal bahkan tidak mampu sama sekali. Hal ini akan menimbulkan kerugian ekonomi yang signifikan untuk penderita sendiri maupun keluarganya. Penderita sendiri tidak mampu bekerja sehingga tidak mempunyai penghasilan dan penghidupannya tergantung kepada orang di sekitarnya terutama keluarganya, sedangkan keluarganya akan mengalami kerugian ekonomi karena harus mengeluarkan biaya caregiver atau perawat atau bahkan keluarganya sendiri yang akan berhenti bekerja untuk menjaga orang dengan Demensia/Alzheimer tersebut. Kerugian ekonomi yang timbul diakibatkan hilangnya penghasilan bagi orang dengen DemensialAlzheimer itu sendiri dan biaya yang harus dikeluarkan untuk mengurus orang dengan DemensialAlzheimer meliputi biaya obatobatan dan pendampingnya (caregiver). Dan apabila pendampingnya adalah anggota keluarganya maka kerugian ekonomi yang timbul berupa hilangnya penghasilan dari anggota keluarga yang berubah fungsi dari pekerja menjadi caregiver.

Senam lansia merupakan bagian dari latihan fisik, latihan fisik adalah segala upaya yang dilaksanakan untuk meningkatkan kebugaran jasmani dan kondisi fisik lansia. Selain senam lansia, berdasarkan penelitian yang dilakukan oleh Pillai et.all (2011) mengatakan bahwa puzzle dapat digunakan untuk memperlambat onset penurunan fungsi kognitif pada lansia. Puzzle adalah suatu gambar yang dibagi menjadi potongan-potongan gambar yang bertujuan untuk mengasah daya pikir, melatih kesabaran, dan membiasakan kemampuan berbagi dan berpikir. Selain itu puzzle juga dapat digunakan untuk permainan edukasi karena dapat mengasah otak dan melatih kecepatan pikiran dan tangan (Misbach, 2010). Menurut penelitian yang dilakukan oleh Pillai et.all (2011) mengatakan bahwa puzzle dengan jenis crossword puzzle dapat digunakan untuk memperlambat onset penurunan fungsi kognitif pada lansia. Selain hal tersebut, upaya untuk menunda kepikunan juga diperlukan dan dapat dilakukan dengan berbagai cara dengan menghindari faktor resiko yang bisa menimbulkan Alzheimer, hidup sehat fisik dan rohani (olahraga teratur dengan makanan 4 sehat 5 sempurna), olahraga teratur untuk lansia bisa dilakukan dengan senam lansia. Adapun cara unik yang bisa dilakukan yaitu dengan memberikan perhatian dan mendengarkan pembicaraan penderita dan mengulang nama penderita yang sedang diajak bicara pada saat pembicaraan berlangsung (Nugroho, 2008). Di Indonesia pada tahun 2010, prevalensi demensia pada lansia yang berumur 65 tahun adalah 5\% dari populasi lansia. Prevalensi ini meningkat menjadi 20\% pada lansia berumur 85 tahun ke atas (Amirullah, 2011).

Di desa Prigen terdapat 10 penderita penyakit Demensia/Alzheimer dimana oleh keluarganya hal ini dianggap sebagai bawaan karena penderita sudah berusia lanjut sehingga pihak keluarga tidak pernah memeriksakan mereka ke Puskesmas. Mereka tidak paham bahwa penyakit Demensia/Alzheimer ini sebenarnya bisa dicegah.

Tujuan diadakannya kegiatan pengabdian kepada masyarakat ini adalah untuk mengedukasi masyarakat agar mereka lebih memahami bahwa Demensia/Alzheimer atau yang umum disebut sebagai 'pikun' merupakan penyakit dan bukan bawaan karena usia lanjut.

Untuk program pengabdian kepada Masyarakat ini Tim Pengabdi sudah melakukan Observasi dengan bidan desa yang merupakan koordinator Posyandu Lansia di Puskesmas Prigen. Berdasarkan data yang ada para lansia yang terdaftar di lingkungan Prigen Barat kecamatan Prigen sebanyak 40 orang.

Permasalahan yang dihadapi oleh mitra antara lain adalah:

Satu, permasalahan bagi lansia yang menderita Demensia/Alzheimer. Solusi yang ditawarkan adalah memberikan edukasi bersama dengan mitra 
mengenai Demensia/Alzheimer sehingga para lansia bisa mencegah terjangkit penyakit ini.

Dua, kurangnya aktivitas olahraga. Solusi yang ditawarkan adalah bekerjasama dengan bidan desa yang merupakan koordinator kelompok lansia untuk memberikan kegiatan edukasi senam yang baik bagi para lansia yang dapat mencegah penyakit Demensia/Alzheimer.

Tiga, kurangnya tenaga edukasi. Solusi yang ditawarkan adalah membantu para lansia memperoleh informasi yang selengkap-lengkapnya mengenai Demensia/Alzheimer.

Manfaat dari kegiatan pengabdian kepada masyarakat ini diharapkan pemahaman masyarakat mengenai penyakit Demensia/Alzheimer ini akan meningkat sehingga mereka bisa melakukan pencegahan sejak dini dengan menerapkan pola hidup sehat dan berolahraga minimal 30 menit setiap hari.

\section{METODE}

Metode yang dipergunakan dalam pelaksanaan program pemberdayaan masyarakat ini dilakukan dengan cara sosialisasi atau memberikan penyuluhan kepada kelompok lansia dengan dibantu oleh bidan desa.

Kegiatan ini diawali dengan pendataan jumlah lansia yang dilakukan oleh bidan desa. Terdapat 40 orang lansia di Desa Prigenm Kecamatan Prigen, Kabupaten Pasuruan.

Kegiatan sosialisasi ini dilakukan secara bertahap karena dilakukan pada masa PPKM darurat dan harus menerapkan prokes yang ketat. Kegiatan ini dibagi menjadi beberapa kelompok guna menghindari kerumunan mengingat tempat diadakannya kegiatan tidak besar. Protocol Kesehatan juga harus diterapkan mengingat yang mengikuti kegiatan ini adalah para lansia yang rentan dengan Virus Covid.

Disamping memberikan penyuluhan tim pengabdi juga membagikan pamflet kepada para lansia. Pamflet ini berisi penjelasan mengenai penyakit Demensia/Alzheimer yang diharapkan kedepannya para lansia ini lebih memahami apa dan bagaimana penyakit Demensia/Alzheimer ini dan cara mencegahnya.

Adapun pamflet yang dibagikan kepada para lansia ada 2 macam. Pamflet pertama berisi gejala umum pada penderita Demensia/Alzheimer dan pamflet kedua berisi cara-cara pencegahan Demensia/Alzheimer.

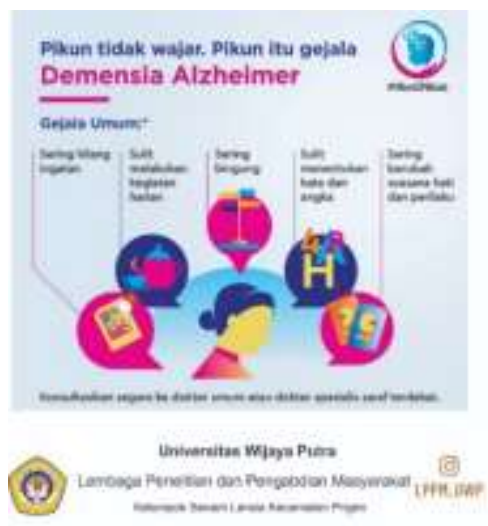

\section{Gambar 1. Gejala Umum Pada Penderita Demensia/Alzheimer}

Gejala umum yang biasanya terjadi pada penderita Demensia/Alzheimer dimana gejala tersebut biasanya adalah sering hilang ingatan, sulit melakukan kegiatan harian, sering bingung, sulit menentukan kata dan angka serta sering berubah suasana hati dan perilaku.

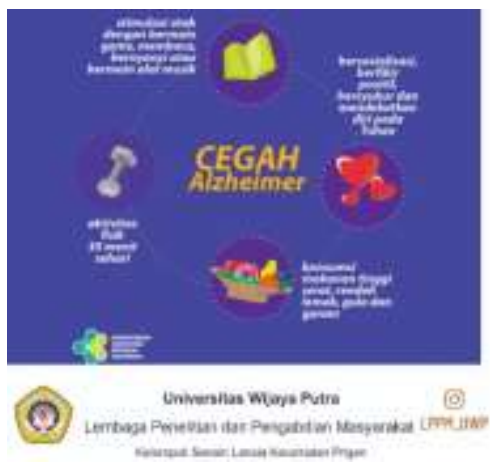

\section{Gambar 2. Cara-Cara Pencegahan Demensia/Alzheimer}

Pamflet berikutnya berisi cara-cara 
pencegahan Demensia/Alzheimer. Disebutkan di dalam pamflet jika pencegahan Demensia/Alzheimer bisa dilakukan dengan beberapa cara antara lain adalah dengan melakukan stimulasi otak dengan bermain game, membaca, bernyanyi atau bermain alat musik; bersosialisasi, berfikir positif, bersyukur dan mendekatkan diri pada Tuhan; mengkonsumsi makanan tinggi serat, rendah lemak, gula dan garam; dan yang terakhir adalah beraktivitas fisik selama 30 menit sehari.

\section{HASIL DAN PEMBAHASAN}

\section{Pelaksanaan Kegiatan}

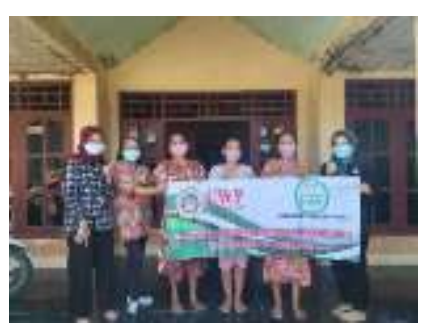

Gambar 3. Pelaksanaan Kegiatan

Kegiatan ini dilaksanakan di Desa Prigen, Kecamatan Prigen, Kabupaten Pasuruan. Salah satu alasan tim pengabdi melakukan kegiatan pengabdian kepada masyarakat ini adalah karena informasi mengenai bahaya penyakit Demensia/Alzheimer ini dirasa masih kurang.

Sasaran dari kegiatan ini adalah para lansia masyarakat desa Prigen yang menjadi anggota posyandu lansia maupun tidak. Kegiatan ini dilaksanakan pada tanggal 9 September 2021, jam 09.00 WIB. Materi yang disampaikan adalah apa dan bagaimana penyakit Demensia/Alzheimer itu dan cara pencegahannya.

Maka dari itu tim pengabdi berusaha memberikan informasi yang selengkap-lengkapnya mengenai penyakit Demensia/Alzheimer ini dengan membagikan pamflet dan mengedukasi para lansia mengenai penyakit ini. Pemahaman mereka mengenai apa dan bagaimana penyakit ini menjadi lebih baik dari sebelumnya.

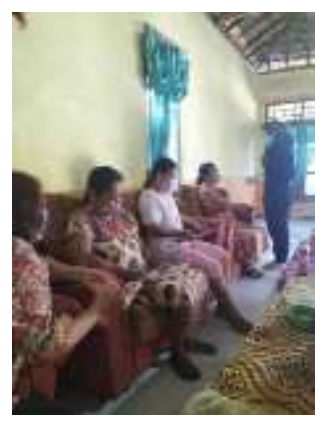

\section{Gambar 4. Pemeriksaan Kesehatan Sebelum Kegiatan Dimulai}

Sebelum kegiatan pelaksanaan pengabdian kepada masyarakat ini dimulai, tim pengabdi memberikan pemeriksaan kesehatan gratis kepada kelompok lansia. Pemeriksaan tersebut antara lain adalah pemeriksaan kadar oksigen dan pemeriksaan tendi darah. Hasil dari pemeriksaan ini ada beberapa orang yang tensi darahnya tinggi tetapi tidak dalam kondisi membahayakan.

Pertama-tama yang dilakukan oleh tim pengabdi adalah mendata terlebih dahulu para lansia yang hadir dalam pelaksanaan kegiatan ini. Data yang diperlukan adalah nama, alamat, nomor telepon dan keluhan yang dirasakan. Setelah data didapatkan barulah beranjak ke proses berikutnya.

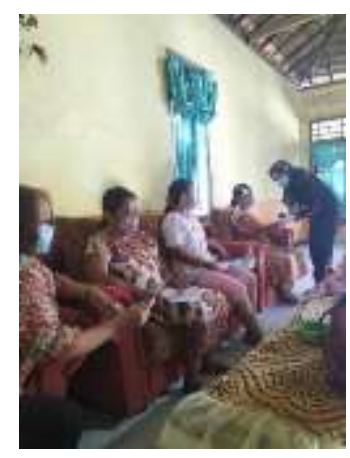

\section{Gambar 5. Pemeriksaan Tensi Darah Pada Kelompok Lansia}

Kemudian dilakukan pemeriksaan tensi darah kepada para lansia peserta kegiatan pengabdian kepada masyatakat ini. 
Dari hasil pemeriksaan tensi darah ini ditemui beberapa lansia mempunyai tensi darah yang tinggi tetapi masih dalam kondisi tidak membahayakan. Tetapi tetap saja mereka harus menjaga kesehatan supaya tensi darah mereka tidak naik lebih tinggi lagi yang dapat mengakibatkan stroke.

Tim pengabdi memberikan penjelasan kepada para lansia bahwa tensi darah juga harus diperhatikan jangan sampai tensi darah mereka melewati ambang batas normal yang bisa menimbulkan stroke dan dapat memicu terjadinya Demensia/Alzheimer.

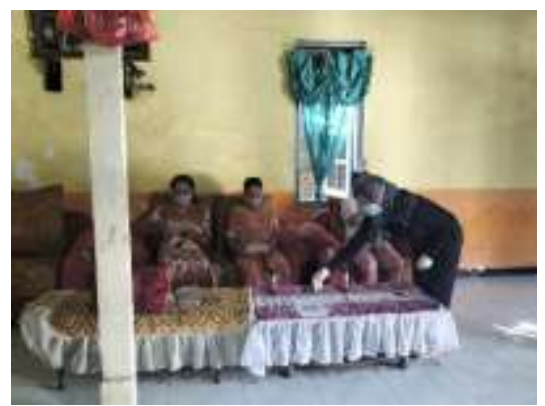

\section{Gambar 6. Pemeriksaan Kadar Oksigen pada Kelompok Lansia}

Setelah itu dilakukan pemeriksaan kadar oksigen kepada para peserta. Dan hasil pemeriksaan oksigen menunjukkan jika kadar oksigen para peserta dalam ambang batas normal.

Dari hasil pemeriksaan kesehatan ini dapat disimpulkan bahwa kesehatan para lansia peserta kegiatan pengabdian kepada masyarakat ini dalam kondisi baik. Tidak ada keluhan yang berarti selain keluhan yang lazim terjadi pada lansia.

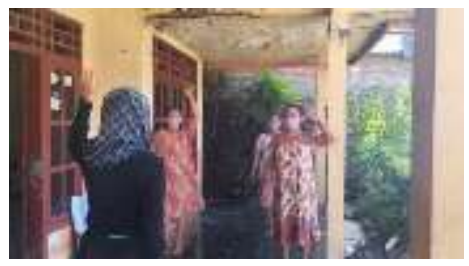

Gambar 7. Gerakan Senam Lansia
Setelah semua tahap dilalui maka sampailah pada puncak kegiatan yaitu sosialisasi senam lansia untuk mencegah Demensia/Alzheimer.

Dikarenakan kegiatan ini dilakukan pada masa PPKM darurat dan untuk menghindari kerumunan maka kegiatan ini dibagi menjadi beberapa kelompok.

Ada yang mengikuti senam ada yang mengikuti penjelasan tim pengabdi melalui pamflet yang telah dibagikan di awal kegiatan ini. Jadi para lansia secara bergantian mengikuti kegiatan ini.

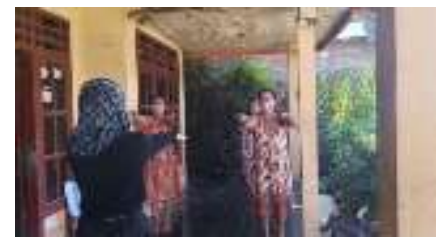

Gambar 8. Gerakan Senam Lansia

Tim pengabdi melakukan senam lansia bersama dengan peserta. Memberikan contoh senam lansia yang mudah diingat oleh para peserta dan bisa dilakukan secara mandiri dimana saja.

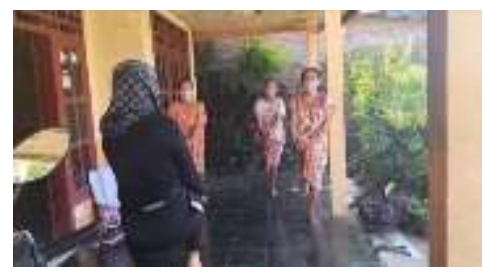

Gambar 9. Gerakan Senam Lansia

Kegiatan senam ini tidak memakan waktu yang lama. Di samping karena gerakan senam sangat mudah untuk diikuti tim pengabdi juga memberikan video senam kepada para lansia melalui aplikasi whatsapp untuk memudahkan mereka melakukan senam jika ada gerakan yang terlupa.

Adapun dampak dari kegiatan ini diharapkan pemahaman masyarakat akan penyakit Demensia/Alzheimer ini lebih baik. Sehingga mereka bisa melakukan pencegahan secara dini. Masyarakat yang dulunya hanya menganggap penyakit ini adalah penyakit orang tua, setelah 
dilakukan kegiatan ini mereka lebih sering berolahraga dan menjaga Kesehatan agar terhindar dari penyakit ini.

Potensi keberlanjutan dari program pemberdayaan masyarakat ini adalah diharapkan untuk tetap menjalin kerjasama antara mitra dan pengabdi dalam melakukan edukasi kesehatan di masyarakat untuk masa yang akan datang. Sehingga bisa tercipta tatanan masyarakat yang sehat.

\section{Target Luaran}

Target luaran yang ingin dicapai dari pelaksanan kegiatan pengabdian kepada masyarakat ini antara lain adalah:

Satu, aspek permasalahan lansia yang menderita Demensia/Alzheimer dimana informasi tentang penyakit ini pada lansia dirasa kurang. Target luaran yang diharapkan adalah dengan adanya edukasi mengenai apa dan bagaimana penyakit Demensia/Alzheimer ini serta bagaimana cara mencegahnya sehingga jumlah penderita Demensia/Alzheimer bisa ditekan.

Dua, aspek permasalahan kurangnya aktivitas olahraga dimana banyak lansia yang kurang aktivitas olahraganya yang berujung pada kemalasan sehingga syaraf yang ada pada tubuh kurang bekerja sempurna. Target luaran yang diharapkan adalah lansia rajin melakukan senam agar tubuhnya bisa tetap bugar dan yang terpenting adalah bisa mencegah terjangkit penyakit Demensia/Alzheimer.

Tiga, aspek permasalahan tenaga edukasi dimana ada lansia di daerah Prigen yang belum terjangkau dan belum memahami penyakit Demensia/Alzheimer ini. Target luaran yang diharapkan adalah dengan adanya edukasi mengenai apa dan bagaimana penyakit Demensia/Alzheimer ini, lansia bisa lebih paham akan penyakit ini dan bisa melakukan pencegahan secara mandiri dari terjangkit penyakit tersebut.
Kesimpulan dari kegiatan pelaksanaan pengabdian kepada masyarakat ini antara lain adalah:

Satu, pemberian edukasi kepada kelompok lansia yang dibantu oleh bidan desa berjalan dengan baik..

Dua, kegiatan edukasi senam lansia berjalan dengan baik. Hal ini dibuktikan dengan meningkatnya jumlah lansia yang melakukan aktivitas olahraga minimal 30 menit sehari dan melakukan senam lansia secara mandiri.

Tiga, kegiatan tenaga edukasi lansia yang belum memadai dimana masih ada lansia yang belum terjangkau oleh tenaga edukasi berjalan dengan baik.

Hasil dari program pengabdian kepada masyarakat ini antara lain adalah tingkat pemahaman masyarakat terhadap penyakit Demensia/Alzheimer ini semakin baik sehingga mereka bisa melakukan pencegahan mandiri terhadap penyakit ini. Meningkatnya jumlah lansia yang melakukan aktivitas olahraga minimal 30 menit sehari dan melakukan senam lansia secara mandiri. Dari yang sebelumnya 40 orang sesudah diadakannya program pengabdian kepada masyarakat ini meningkat menjadi 53 orang.

\section{SARAN}

\section{Bagi masyarakat.}

Diharapkan dengan adanya program pemberdayaan masyarakat yang dilaksanan di Desa Prigen, Kecamatan Prigen, Kabupaten Pasuruan ini ke depannya diharapkan dapat terjalin kerjasama yang bekelanjutan

\section{Bagi Universitas.}

Untuk lebih aktif mendorong diadakannya pengabdian kepada masyarakat yang dapat meningkatkan pengetahun maupun taraf hidup masyarakat di sekitar Kampu Universitas Wijaya Putra Surabaya.

\section{KESIMPULAN}

Kesehatan 386 


\section{Bagi Tim Pengabdi.}

Lebaih banyak lagi menggali potensi diri dan berpikir kreatif untuk mencari ide-ide yang bisa diterapkan pada program pengabdian masyarakat dengan melakukan kegiatan yang lebih bermanfaat ke depannya.

\section{UCAPAN TERIMAKASIH (Bila ada)}

Ucapan terimakasih disampaikan kepada Lembaga Penelitian dan Pengabdian Kepada Masyarakat Universitas Wijaya Putra Surabaya yang telah memberikan kontribusi dalam pelaksanaan kegiatan pengabdian ini dengan memberikan pendanaan internal universitas.

\section{REFERENSI}

Amirullah. 2011. Jumlah Orang Pikun Indonesia Meningkat. https://www.tempo.co/read/news/2011/12/0 6/060370238/Jumlah-Orang-PikunIndonesia-Meningkat. (diakses tanggal 20 April 2021)

Beda Gejala Dimensia dan Alzheimer. (2020, Feb 19).

https://health.kompas.com/read/2020/02/19/0 90500268/beda-gejala-demensia-danalzheimer-serupa-tapi-tak-sama?page $=$ all.

Hatmanti, Nety Mawarda dan Yunita, Ana. (2019). Senam Lansia dan Terapi Puzzle Terhadap Demensia pada Lansia. Jurnal Keperawatan Muhammadiyah, 4 (1). pp. 104-107. ISSN 2597-7539

Misbach. (2016). Media Puzzle (online). Diakses 20 April 2021.

Nugroho, Wahjudi. (2008). Keperawatan Gerontik $\&$

Geriatrik. Edisi 3. Jakarta; EGC.

Pillai et al. (2014). Association Of Crossword

\section{Puzzle}

Pastisipation with Memory Decline in Person Who Develop Dementia. https://www.ncbi.nlm.nih.gov. 